\title{
Comparison of Knowledge, Attitude, and Motivation-to-Breastfeed Exclusively between Allied Health Students and Students of Other Fields at Universitas Padjadjaran
}

\author{
Sri Astuti, Tina Dewi Judistiani, Lina Rahmiati, Ari Indra Susanti \\ Department of Public Health Universitas Padjadjaran
}

\begin{abstract}
University students are among future intellectuals who will play an important role in community education and empowerment, especially on the topic of exclusive breastfeeding, in which the coverage is low in Indonesia. This study aimed to compare students' knowledge, attitude, and motivation-to-breastfeed exclusively between allied health studies (AHS), i.e medicine and midwifery, and other fields studies (OFS), i.e. psychology, communication, literacy, and farming. Further information will be gained from exploring the correlation of knowledge-attitude, as well as attitude - motivation in both groups. A study was conducted among Indonesian female students in their final year of bachelor degree in October to November 2013. The subjects recruited were 196/340 female AHS and 300/633 female OFS. The remaining students were absent at data collection time. Validity and reliability of the questionnaires were satisfactory. Ethical clearance was obtained from the Committee on Health Research Ethics, Faculty of Medicine, Universitas Padjadjaran. The mean scores must be higher than the cut off points to pass. Student's T test result showed a highly significant difference (AHS vs OFS group: 83.1 vs 71.1 for knowledge, 91.3 vs 86.4 for attitude, and 88.3 vs 83.6 for motivation-to-breastfeed exclusively, $p<0.001$ ). It is revealed also that the correlation index between knowledge-attitude as well as attitude - motivation-to- breastfeed exclusively were higher in AHS group, but some AHS students scored lower than the OFS students. Discussion on this topic is presented in this article. Corrective interventions are needed for students who scored low. This study shows a satisfactory students' scores of knowledge, attitude, motivation-to-breastfeed exclusively. The AHS group has a better performance and correlation index between knowledge and attitude, attitude and motivation-tobreastfeed exclusively. [MKB. 2016;48(3):176-80]
\end{abstract}

Key words: Allied health students, attitude, knowledge, motivation-to-breastfeed exclusively, students of other fields

\section{Hubungan antara Pengetahuan dan Perilaku, serta Motivasi Menyusui pada Mahasiswi Fakultas Medis dan Non-medis di Universitas Padjadjaran}

\begin{abstract}
Abstrak
Mahasiswi universitas yang keberadaanya di antara para intelektual masa depan mempunyai peran penting dalam pendidikan dan pemberdayaan masyarakat, khususnya mengenai air susu ibu (ASI) eksklusif yang mempunyai cakupan rendah di Indonesia. Penelitian ini bertujuan membandingkan pengetahuan, sikap, dan motivasi untuk menyusui secara eksklusif antara beberapa studi kesehatan (AHS), yaitu kedokteran dan kebidanan, serta studi bidang lain (OFS), yaitu psikologi, komunikasi, sastra, dan pertanian. Informasi lebih lanjut akan mengeksplorasi hubungan pengetahuan, sikap, serta sikap-motivasi pada kedua kelompok. Penelitian ini dilakukan dari OktoberNovember 2013. Sampel terdiri atas 196/340 perempuan AHS dan 300/633 OFS perempuan di Universitas Padjadjaran. Sampel yang tidak diambil adalah mahasiswi yang tidak hadir pada saat pengumpulan data. Validitas dan reliabilitas kuesioner yang memuaskan. Izin etik diperoleh dari Komite Etik Penelitian Kesehatan Fakultas Kedokteran Universitas Padjadjaran. Hasil nilai yang lebih tinggi mempunyai poin untuk lulus. Hasil uji-t mahasiswi menunjukkan perbedaan yang sangat signifikan (AHS vs kelompok OFS adalah 83,1 vs 71,1 untuk pengetahuan, 91,3 vs 86,4 sikap, dan 88,3 vs 83,6 motivasi untuk menyusui secara eksklusif, p<0,001). Indeks korelasi antara pengetahuan dan sikap serta sikap dengan motivasi untuk menyusui secara eksklusif lebih tinggi pada kelompok AHS, namun beberapa mahasiswi AHS mempunyai nilai lebih rendah daripada mahasiswi OFS. Hal tersebut dibahas dalam artikel, intervensi korektif yang diperlukan antara mahasiswi yang mendapat nilai rendah. Penelitian ini menunjukkan hasil yang memuaskan pada nilai mahasiswi tentang pengetahuan, sikap, dan motivasi untuk menyusui secara eksklusif. Kelompok AHS menunjukkan kinerja dan indeks korelasi yang lebih baik antara pengetahuan dan sikap, sikap dengan motivasi untuk menyusui secara eksklusif. [MKB. 2016;48(3):176-80]
\end{abstract}

Kata kunci: Mahasiswi kesehatan, motivasi untuk menyusui secara eksklusif, mahasiswi non-kesehatan, sikap dan pengetahuan

Korespondensi: Dra. Sri Astuti, M.Kes, Departemen Ilmu Kesehatan Masyarakat Fakultas Kedokteran Universitas Padjadjaran Bandung, Jalan Prof. Eijkman No. 38 Bandung, mobile 08122353282,e-mail sriastuti29a@gmail.com 


\section{Introduction}

Exclusive breastfeeding is the best way to feed infants up to 6-month old. The most important rationale for the practice is the antibody content of breastmilk which helps infant immune system to fight infection providing much better survival in the first year of life. ${ }^{1}$ The content of breastmilk is also known best to ensure infant growth. Breastfeeding process increases mother-infant bonding which also help development during infancy and later life. Some reports also showed that breastfeeding reduces the risk of infant sudden death syndrome., ${ }^{2,3}$ The success of breastfeeding in the early post partum period promotes continuity of the practice, therefore the earliest exposure to promote breastfeeding as early as possible is paramount. The appropriate timing and technique of breastfeeding start is also important. A report stated that skin to skin contact and baby's suckling will stimulate breastmilk production especially in the first thirty minutes. ${ }^{4}$

Early breastfeeding for the first hour of life reduced neonatal mortality rate by $22 \%$. $^{1,2}$ This means that early education, promotion of breastfeeding may start premarital, preconception or at least during pregnancy. ${ }^{5-8}$ The fact that exclusive breastfeeding has not been practiced to its maximum potentials in Indonesia is supported by year 2012 and 2014 Health Statistics which showed that only $42 \%$ and $52.3 \%$ of breastfeeding mothers did so. ${ }^{9,10}$ The actual goal is $80 \%$ but unfortunately West Java ranked lowest by $21.8 \%$ exclusive brestfeeding coverage. ${ }^{10}$

Misconception such as primiparas are less prepared for breastfeeding both physically and emotionally, can be changed. The higher value of breasts for other purposes such as cosmetic reasons than breastfeeding needs to shifted. Others constraints such as lack of knowledge on the advantages of early breastfeeding, cultural perspectives on births fluid and birth dirt, miss management of maternal post partum fatigue, discomfort that allows breastfeeding postponement or pauses, should be dealt with. ${ }^{11,12}$

More support from the community in all setting needs to be increased, such as antenatal education and postnatal support strategies for improving rates of exclusive breast feeding, providing nursing and breastfeeding spaces in office and public places should be endorsed., ${ }^{8,13}$

In 1990 World Health Organizations (WHO) adopted the Innocenti Declaration, on the Protection, Promotion and Support of Breastfeeding. Until today WHO also suggests that all mothers perform exclusive breastfeeding, to give only breast milk to infant up to 6 months old. Until then additional food could be given to accompany breastfeeding up to 2 years of age. ${ }^{1}$

Despite the efforts to spread and implement this policies worldwide, studies showed that only fractions of mothers breastfeed exclusively ranging from $40 \%$ to $50 \%$ + in different countries., $90,14,15$ Other barriers to breastfeeding found from studies in the United States and Sweden were 'not liking breastfeeding', 'nipple pain', and maternal inconfidence that their breastmilk would suffice, especially among young mothers. ${ }^{13}$

The Indonesian government has also produced various action policies on enhancing breastfeeding practices especially among expecting mothers and breastfeeding periods. Specific policy designed to include these matters at educational level in general is not yet available. Our perspective is that at any education levels teenagers and young women can be exposed to correct information about the importance of breastfeeding and building support for the practice. Some of breastfeeding problems may not surface if women had been informed about the benefits of breastfeeding and prepared mentally for exclusive breastfeeding since they were young.,6

University students are in unique position as to being recipients of valid information on breastfeeding issues. University students will often play an important role in information exchanges between their peers, family and the community as a whole, during education period or after they graduate. Peer and professional support relieved mothers from anxiety, fear, or even ignorance of breastfeeding. ${ }^{5}$ A pilot study in Jordan was conducted among medical and non medical students which showed that there was discrepancies in their opinions about breastfeeding. ${ }^{8}$

For this study purpose only, classify students into allied health students (AHS), i.e. medical and midwifery, and students of other fields (OFS). Students of the OFS group were recruited from 4 different schools, i.e psychology, farming, literacy and communication.

In our perspectives, members of AHS group have the privilege of acquiring more amount and correct information on exclusive breastfeeding as compared to OFS as a result of their study choice. Even though access to such information is abundant for the community as a whole, it is 
important to study if there is any difference in knowledge and attitude towards breastfeeding between AHS and OFS group. Furthermore, we would also like to know if one's knowledge and attitude towards breastfeeding positively correlated with one's motivation to later practice of breastfeeding.

\section{Methods}

A cross sectional study was carried out to find out the whether there was any difference in knowledge and attitude towards breastfeeding between female AHS and OFS. Students of the OFS group were recruited partly based on their common prospective role of in health promotions in society.

Indonesian female students in the end of their final year of bachelor degree, as well as diploma degree for midwifery education, assuming they have gathered as much as possible information of breastfeeding and its related issues during their life time. It was interesting for us to reveal whether they have developed the motivation to perform breastfeeding even much earlier and also to determine if better knowledge and attitude correlated with their motivation level in the two groups. Ethical clearance was released from Health Research Ethics Committee Faculty of Medicine Universitas Padjadjaran.

Students were informed in advance about the schedule of this study. We expected to recruit all population of AHS and OFS, and obtain their written consent to participate. Students age and marital status were considered as possible confounding factors.

A set of questionnaires were developed to measure the knowledge of breastfeeding and breastmilk (43, true-false questions), attitude towards breastfeeding (17 questions on likert scales) and motivation to breastfeed (15 questions on likert scales). The test for validity and reliability of the questionnaires showed satisfactory result. Statistical tests used in analysis are mentioned correspondingly.

\section{Results}

On the day of data collection, only 196 out of 340 female AHS and 300 out of 633 female OFS were available and recruited. The students' average age in the two groups were similar, while only one student was married, therefore the two groups were comparable (data not shown).

Table 1 shows that in general students in AHS group showed significantly better scores in knowledge, behaviour, and motivation compared to students in OHS group. Student's t test support the significance of the difference between the groups.

Descriptive result showed that minimum scores for knowledge and attitude were lower in OHS group, but AHS group yielded lower minimum score of motivation. When arbitrarily set the lowest acceptable score of 56 for all variables, the OHS group had $6.3 \%$ of students who failed to pass the knowledge test and $22.4 \%$ of students failed in showing supportive attitude towards breastfeeding. However, a surprising results came out that in the AHS group still had $1.5 \%$ of students who failed to produce adequate score in motivation to breastfeed.

The descriptive results above raised two new question, i.e what could be the problems among AHS students who scored lower enough to effect the group's average score in motivation to breastfeed and even some AHS students failed to reach passing score in motivation.

Tabel 2 shows result of analysis on correlation

Tabel 1 Comparison of Knowledge, Attitude and Motivation Scores

\begin{tabular}{lccc}
\hline & $\begin{array}{c}\text { OFS } \\
\mathbf{N = 3 0 0}\end{array}$ & $\begin{array}{c}\text { AHS } \\
\mathbf{n = 1 9 6}\end{array}$ & p Value \\
\hline Knowledge & $71.1(9.3)$ & $83.1(6.8)$ & 0.000 \\
$\quad$ Mean $( \pm$ SD) & $21.4-90.5$ & $61.9-95.2$ & \\
$\quad$ Range & & & \\
Attitude & $86.4(-8.7)$ & $91.3(6.4)$ & 0.000 \\
$\quad$ Mean $( \pm$ SD) & $19.1-100$ & $64.7-100$ & 0.000 \\
$\quad$ Range & & & \\
Motivation & $83.6(10.3)$ & $39-3(9.5)$ & \\
$\quad$ Mean $( \pm S D)$ & $51.7-100$ & & \\
$\quad$ Range & &
\end{tabular}

Comparisons of means by student's T test. 
Table 2 Correlation between Knowledge- Attitude and Attitude-Motivation on Breastfeeding within All Groups

\begin{tabular}{ccccc}
\hline \multirow{2}{*}{ Variables } & \multicolumn{2}{c}{$\begin{array}{c}\text { AHS } \\
(\mathbf{n = 1 9 6})\end{array}$} & \multicolumn{2}{c}{$\begin{array}{c}\text { OHS } \\
(\mathbf{n}=\mathbf{3 0 0})\end{array}$} \\
\cline { 2 - 5 } & $\mathbf{r}$ & $\mathbf{p}$ Value & $\mathbf{r}$ & $\mathbf{p}$ value \\
\hline Knowledge and attitude & 0.373 & $<0,001$ & 0.284 & $<0.001$ \\
Attitude and motivation & 0.553 & $<0,001$ & 0.470 & $<0.001$ \\
\hline
\end{tabular}

Correlation index (r) by Pearson

between the three aspects of knowledge, attitude and motivation to breastfeed within all groups by Pearson test. Knowledge and behavior, knowledge and motivation, motivation and behavior all proved positively correlated, highly significant, within both groups $(\mathrm{p}<0.001)$. Correlation index was highest between attitude and motivation.

\section{Discussion}

This study showed that having the advantage on their study subjects, students in AHS group had highly significant higher mean scores for knowledge, attitude and motivation than students in OFS group. Students in the OFS group did not get any subject of breast feeding in their curriculum.

As expected, the correlation index between knowledge and attitude was higher in the AHS group than OFS group. Similar situations also played for correlation index between attitude and motivation to breastfeed. The correlation index of knowledge to attitude in AFS and OHS groups $(r=0.373$ and $r=0.284)$ may play a role in the increase in correlation index between attitudemotivation ( $\mathrm{r}=0.553$ and $\mathrm{r}=0.47)$ respectively. Further analysis showed that the difference in correlation index between two groups reached statistical significance.

As an addition to analysis we tried to find out what aspect of knowledge need to be upgraded especially in the AHS group. The result turned out that the smallest portion of students (30$40 \%$ ) answered correctly the questions on how to store breast milk, to warm and to serve it again after being frozen and that breast milk should not be mixed with powdered milk. This is a very important issue to be addressed correctly by health workers since nowadays the number of breastfeeding woman who work is also huge.

Two aspects in attitude toward breast milk which scored lowest, were from the statements that formula milk is superior for its enrichments and that providing expensive formula milk is more prestigious. This is also a big issue in a way that despite the banning for formula milk commercials has been established, it showed that cultural (wrong) value did not simply go away.

In the area of motivation to breastfeed most respondents did not find that the socioeconomic-cultural advantage of breastfeeding were the stronger drive to breastfeed compared to its impact on infants health. This may relate to the general knowledge of breast milk contents that they already knew.

The anomaly in this study is that there were 5 AHS students who scored very low in motivation to breastfeed, failing to pass the lowest expected score (56) even lower than that lowest score of OFS student (51). Their knowledge were also the lowest in the AHS group. Among these students special discussion and corrective intervention would be held to improve their knowledge, attitude and motivation to breast feed. In Conclusion Students in AHS group had highly significant higher mean scores for knowledge, attitude and motivation than students in OFS group.

The correlation index between knowledge and attitude was higher in the AHS group than OFS group. The correlation index between attitude and motivation to breastfeed was higher in the AHS group than OFS group. Some materials needs to be updated in the allied health science curriculum especially on how to store breast milk, to warm and to serve it again after being frozen and that breast milk should not be mixed with powdered milk. In the promotion effort, reemphasizing breastfeeding additional value, i.e. the socio-economic-cultural advantage of breast milk should be rehearsed to increase positive attitude towards breastfeeding.

Corrective intervention among AHS students who scored lowest in motivation to breastfeed should be well planned to ensure improvement. 


\section{References}

1. United Nations Children's Fund. Breastfeeding counselling: a training course. Geneva: World Health Organization; 1993.

2. Hauck FR, Thompson JM, Tanabe KO, Moon RY, Vennemann MM. Breastfeeding and reduced risk of sudden infant death syndrome: a meta-analysis. Pediatrics. 2011; 128(1):103-10.

3. Chapman DJ. New evidence: exclusive breastfeeding and reduced sudden infant death syndrome risk. J Hum Lact. 2011; 27(4):404-5.

4. Finigan V. The experiences of women from three diverse population groups of immediate skin-to-skin contact with their newborn baby following birth. Salford: University of Salford; 2010.

5. Chapman DJ, Morel K, Anderson AK, Damio G, Perez-Escamilla R. Breastfeeding peer counseling: from efficacy through scale-up. J Hum Lact. 2010;26(3):314-26.

6. Dhandapany G, Bethou A, Arunagirinathan A, Ananthakrishnan S. Antenatal counseling on breastfeeding - is it adequate? A descriptive study from Pondicherry, India. Int Breastfeed J. 2008;3(1):5.

7. SuL, Chong Y, Chan Y, Chan Y, Fok D, Tun K, dkk. Antenatal education and postnatal support strategies for improving rates of exclusive breast feeding: randomised controlled trial. Br Med J. 2007;335(7620):596-612.

8. Al-Ali N, Hatamleh R, Khader Y. Female public Jordanian university undergraduate students intentions and attitudes toward breastfeeding application of selfobjectification theory. Breastfeeding review professional publication of the Nursing Mothers' Association Australia. 2013;21(3): 31-42.

9. Kementrian Kesehatan Indonesia. Profil Kesehatan Indonesia Health Stastistics. Jakarta: Kemenkes RI; 2012.

10. Kementrian Kesehatan Indonesia. Profil Kesehatan Indonesia Health Stastistics. Jakarta: Kemenkes RI; 2014.

11. Finigan V, Long T. Skin-to-skin contact: multicultural perspectives on birth fluids and birth dirt. Int Nursing Rev. 2014;61(2):2707.

12. Daly A, Pollard CM, Phillips M, Binns CW. Benefits, barriers and enablers of breastfeeding: factor analysis of population perceptions in Western Australia. PloS One. 2014;9(2):88204-4.

13. Lamontagne $C$, Hamelin A-M, St-Pierre M. The breastfeeding experience of women with major difficulties who use the services of a breastfeeding clinic a descriptive study. Int Breastfeed J. 2008;3(1):17.

14. Gillespie B, d'Arcy H, Schwartz K, Bobo J, Foxman B. Recall of age of weaning and other breastfeeding variables. Int Breastfeed J. 2006;1(1):4.

15. Promislow J, Gladen B, Sandler D. Maternal recall of breastfeeding duration by elderly women. Am J Epidemiol. 2005;161(1):28996. 